Article

\title{
Free Amino Acids in Three Pleurotus Species Cultivated on Agricultural and Agro-Industrial By-Products
}

\author{
Dimitra Tagkouli ${ }^{1}$, Andriana Kaliora ${ }^{1}$, Georgios Bekiaris ${ }^{2}$ (D) Georgios Koutrotsios ${ }^{2}$, \\ Margarita Christea ${ }^{1}$, Georgios I. Zervakis ${ }^{2, *(D)}$ and Nick Kalogeropoulos ${ }^{1, *(D)}$
}

1 Department of Dietetics-Nutrition, School of Health Science and Education, Harokopio University of Athens, El. Venizelou 70, Kallithea, 17676 Athens, Greece; dtagkoul@hua.gr (D.T.); akaliora@hua.gr (A.K.); mchristea@hua.gr (M.C.)

2 Laboratory of General and Agricultural Microbiology, Agricultural University of Athens, Iera Odos 75, 11855 Athens, Greece; giorgosbekiaris@yahoo.gr (G.B.); georgioskoutrotsios@gmail.com (G.K.)

* Correspondence: zervakis@aua.gr (G.I.Z.); nickal@hua.gr (N.K.); Tel.: +30-210-5294341 (G.I.Z.); +30-210-9549251 (N.K.)

Academic Editor: Gilles Comte

Received: 1 August 2020; Accepted: 31 August 2020; Published: 2 September 2020

\begin{abstract}
Previous studies have demonstrated the feasibility of employing by-products of the olive and wine sectors for the production of Pleurotus mushrooms with enhanced functionalities. In this work we investigated the influence of endogenous and exogenous factors on free amino acids (FAAs) profile of Pleurotus ostreatus, P. eryngii and P. nebrodensis mushrooms produced on wheat straw (WS), alone or mixed with grape marc (GM), and on by-products of the olive industry (OL). Overall, 22 FAAs were determined in substrates and mushrooms, including all the essential amino acids, the neurotransmitter $\gamma$-aminobutyric acid (GABA) and ornithine. On a dry weight (dw) basis, total FAAs ranged from $17.37 \mathrm{mg} / \mathrm{g}$ in P. nebrodensis to $130.12 \mathrm{mg} / \mathrm{g}$ in P. ostreatus samples, with alanine, leucine, glutamine, valine and serine predominating. Similar distribution patterns were followed by the monosodium glutamate (MSG)-like, sweet and bitter FAAs. Significant differences in FAAs level were observed among the species examined and among the cultivation substrates used. Principal Component Analysis (PCA) performed on the entire FAAs profile of six Pleurotus strains, clearly separated P. ostreatus from P. eryngii and P. nebrodensis, in accordance to their phylogenetic affinity. This is the first report of FAAs in P. nebrodensis.
\end{abstract}

Keywords: Pleurotus mushrooms; free amino acids; GABA; bitter amino acids; sweet amino acids; monosodium glutamate-like amino acids; wheat straw; grape marc; olive mill waste; PCA

\section{Introduction}

Edible mushrooms are considered delicacies due to their distinct texture, aroma and exceptional flavor. In addition, they exhibit several health-beneficial effects, e.g., hypocholesterolaemic, antihypertensive, cardioprotective and chemopreventive [1-3]. The world production of cultivated edible mushrooms considerably increased during the last 20 years and has reached 34 billion $\mathrm{kg}$ in 2013, with Pleurotus representing circa 19\% of the total [4]. Amongst the Pleurotus species, P. ostreatus is the most widely cultivated, while $P$. eryngii and $P$. nebrodensis produce mushrooms of exceptional organoleptic properties [5]. Since Pleurotus fungi are efficient in biodegradation of a wide range of lignocellulosic residues and by-products, including those originating from the olive oil and wine sector agro-industries $[6,7]$, their exploitation as mushroom cultivation substrates is of great applied interest. We have previously shown that such materials can be successfully used for the production of 
value-added biomass, i.e., mushrooms enriched with bioactive compounds and enhanced antioxidant activity [8-10].

Amino acids (AAs) not only act as substrates for protein synthesis, but they are also associated with significant health-related effects by being involved in various pathways of cellular communication, gene expression, oxidative stress, immune process and intracellular protein metabolism [11]. In addition, free amino acids (FAAs) together with other non-volatile compounds, such as $5^{\prime}$-nucleotides, soluble sugars and polyols, are considered responsible for the palatable taste of mushrooms [12-16]. As such, the identification of the AAs profile in foods is of particular importance from an organoleptic and physiological point of view, while it is crucial in metabolic research studies and in a wide range of medical and biopharmaceutical applications. Especially in edible mushrooms that are complex matrices rich in beta-glucans, minerals, vitamins and bioactive compounds (i.e., ergosterol, tocopherols, phenolics, organic acids, lovastatin, etc.) $[8,17,18]$, the simultaneous presence of all essential AAs, gamma-aminobutyric acid (GABA) and ornithine further confers to their high nutritional value.

Hereby, we sought to assess the FAAs profile in P. ostreatus, P. eryngii and P. nebrodensis mushrooms, and to investigate how FAAs are influenced by endogenous (through the examination of six Pleurotus strains) and exogenous (by including fruitbodies produced in various cultivation substrates) factors.

\section{Results and Discussion}

Overall, 22 FAAs were detected and quantified in mushroom samples of six Pleurotus strains and in their cultivation substrates.

The FAAs were determined by the EZ:faast ${ }^{\mathrm{TM}}$ kit for GC-MS provided by Phenomenex (Torrance, CA, USA) [19]. The aforementioned kit can measure all the essential and several non-essential AAs, whereas it does not measure the conditionally essential cysteine and arginine, together with citrulline, 1- and 3-methylhistidines and taurine [20].

Depending on their properties, AAs are placed in several groups that portray their essential role in human diet not only in terms of nutritional importance but also as regards their contribution to food palatability. Such groups are: essential AAs that cannot be synthesized by the human body and must be obtained from food sources, umami-taste active or monosodium glutamate (MSG)-like AAs, branched-chain AAs (BCAAs), bitter-taste AAs and sweet-taste AAs (Table 1).

Table 1. Groups of amino acids studied. AA: amino acids; BCAA: branched-chain AAs; MSG: monosodium glutamate.

\begin{tabular}{ccccc}
\hline Essential AAs & BCAAs & MSG-Like AAs & Bitter Taste AAs & Sweet Taste AAs \\
\hline Valine & Valine & Aspartic acid & Valine & Threonine \\
Leucine & Leucine & Glutamic acid & Methionine & Serine \\
Isoleucine & Isoleucine & & Leucine & Glycine \\
Threonine & & Isoleucine & Alanine \\
Methionine & & Phenylalanine & Proline \\
Phenylalanine & & Histidine & \\
Lysine & & Tryptophan & \\
Histidine & & & \\
Tryptophan & & & \\
\hline
\end{tabular}

\subsection{Protein and FAAs Content in Mushroom Cultivation Substrates}

The total content of FAAs detected in mushroom cultivation substrates ranged from $0.33 \mathrm{mg} / \mathrm{g}$ $\mathrm{dw}$ in WS to $0.71 \mathrm{mg} / \mathrm{g} \mathrm{dw}$ in OL and $1.23 \mathrm{mg} / \mathrm{g} \mathrm{dw}$ in GM (Table 2). FAAs profiles exhibited notable differences among substrates, with glutamic acid, glutamine and lysine being the most abundant in WS, representing $69 \%$ of total FAAs; glutamic acid, asparagine, thioproline, aspartic acid, glutamine and proline dominated in GM (circa 60\% of total FAAs) and thioproline, aspartic acid, tryptophan, asparagine and glutamic acid comprised $71 \%$ of total FAAs in OL. Crude protein content of substrates was found equal to $85.2,116.6$ and $129.0 \mathrm{mg} / \mathrm{g} \mathrm{dw}$ in WS, GM and OL, respectively. 
Considering that the GM substrate is composed by equal weights of wheat straw and grape marc, while the OL substrate is composed by olive leaves and two-phase olive mill wastes at 3:1 w/w ratio, the protein content of substrates determined in the present work is in agreement to data provided in the literature for the protein content of substrate components, which increase in the order: olive mill wastes $(4 \mathrm{mg} / \mathrm{g} \mathrm{dw})<$ wheat straw $(43 \mathrm{mg} / \mathrm{g} \mathrm{dw})<$ grape pomace $(110-160 \mathrm{mg} / \mathrm{g} \mathrm{dw})<$ olive leaves $(196 \mathrm{mg} / \mathrm{g} \mathrm{dw})$ [21,22].

Table 2. Free amino acids and crude protein content in the mushroom cultivation substrates used.

\begin{tabular}{ccccc}
\hline Amino acid & Abbreviation & WS & GM & OL \\
\hline Alanine & Ala & $0.003 \pm 0.001 \mathrm{a}$ & $0.065 \pm 0.007 \mathrm{c}$ & $0.023 \pm 0.005 \mathrm{~b}$ \\
Glycine & Gly & $0.002 \pm 0.001 \mathrm{a}$ & $0.022 \pm 0.004 \mathrm{c}$ & $0.009 \pm 0.000 \mathrm{~b}$ \\
Valine & Val & $0.002 \pm 0.001 \mathrm{a}$ & $0.010 \pm 0.002 \mathrm{~b}$ & $0.004 \pm 0.000 \mathrm{a}$ \\
Leucine & Leu & $0.008 \pm 0.005 \mathrm{a}$ & $0.032 \pm 0.006 \mathrm{~b}$ & $0.008 \pm 0.001 \mathrm{a}$ \\
Isoleucine & Ile & $0.004 \pm 0.002 \mathrm{a}$ & $0.019 \pm 0.004 \mathrm{~b}$ & $0.006 \pm 0.001 \mathrm{a}$ \\
Threonine & Thr & $0.004 \pm 0.002 \mathrm{a}$ & $0.020 \pm 0.005 \mathrm{~b}$ & $0.006 \pm 0.000 \mathrm{a}$ \\
Serine & Ser & $0.005 \pm 0.002 \mathrm{a}$ & $0.043 \pm 0.003 \mathrm{c}$ & $0.012 \pm 0.001 \mathrm{~b}$ \\
Proline & Pro & $0.004 \pm 0.001 \mathrm{a}$ & $0.091 \pm 0.020 \mathrm{~b}$ & $0.022 \pm 0.001 \mathrm{a}$ \\
Asparagine & Asn & $0.003 \pm 0.001 \mathrm{a}$ & $0.137 \pm 0.002 \mathrm{c}$ & $0.061 \pm 0.015 \mathrm{~b}$ \\
Thioproline & Thp & $0.013 \pm 0.005 \mathrm{a}$ & $0.105 \pm 0.003 \mathrm{c}$ & $0.147 \pm 0.004 \mathrm{~b}$ \\
Aspartic acid & Asp & $0.012 \pm 0.003 \mathrm{a}$ & $0.097 \pm 0.006 \mathrm{c}$ & $0.138 \pm 0.003 \mathrm{~b}$ \\
Methionine & Met & $0.003 \pm 0.002 \mathrm{a}$ & $0.001 \pm 0.001 \mathrm{a}$ & nd \\
Hydroxyproline & Hyp & nd & $0.003 \pm 0.001$ & nd \\
Glutamic acid & Glu & $0.155 \pm 0.026 \mathrm{a}$ & $0.204 \pm 0.002 \mathrm{c}$ & $0.064 \pm 0.002 \mathrm{~b}$ \\
Phenylalanine & Phe & $0.006 \pm 0.003 \mathrm{a}$ & $0.024 \pm 0.005 \mathrm{~b}$ & $0.006 \pm 0.000 \mathrm{a}$ \\
Glutamine & Gln & $0.037 \pm 0.010 \mathrm{a}$ & $0.093 \pm 0.003 \mathrm{~b}$ & $0.037 \pm 0.004 \mathrm{a}$ \\
Ornithine & Orn & $0.022 \pm 0.000 \mathrm{a}$ & $0.025 \pm 0.001 \mathrm{~b}$ & $0.022 \pm 0.000 \mathrm{a}$ \\
Lysine & Lys & $0.033 \pm 0.001 \mathrm{a}$ & $0.057 \pm 0.006 \mathrm{~b}$ & $0.035 \pm 0.001 \mathrm{a}$ \\
Histidine & His & $0.0003 \pm 0.000 \mathrm{a}$ & $0.023 \pm 0.005 \mathrm{~b}$ & $0.002 \pm 0.000 \mathrm{a}$ \\
Tyrosine & Tyr & $0.006 \pm 0.002 \mathrm{a}$ & $0.018 \pm 0.003 \mathrm{~b}$ & $0.008 \pm 0.001 \mathrm{a}$ \\
Tryptophan & Trp & $0.001 \pm 0.001 \mathrm{a}$ & $0.085 \pm 0.001 \mathrm{~b}$ & $0.093 \pm 0.009 \mathrm{~b}$ \\
$\gamma$-Aminobutyric acid & GABA & nd & $0.058 \pm 0.003 \mathrm{a}$ & $0.008 \pm 0.002 \mathrm{~b}$ \\
Sum of amino acids & & $0.319 \pm 0.070$ & $1.231 \pm 0.077$ & $0.711 \pm 0.033$ \\
Crude protein & & $85.20 \pm 4.34 \mathrm{a}$ & $116.60 \pm 5.04 \mathrm{~b}$ & $131.12 \pm 0.09 \mathrm{c}$ \\
\hline Val & & a & &
\end{tabular}

Values $(\mathrm{mg} / \mathrm{g}$ dry weight) represent the means $\pm \mathrm{SD}(n=3)$. Lack of letters in common indicates statistically significant differences (Duncan's t-Test. $p<0.05$ ) in comparisons of treatment means between different substrates. Abbreviations: WS, wheat straw; GM, wheat straw with grape marc (1:1 w/w ratio); OL, olive leaves with olive mill wastes $(3: 1 w / w)$; nd, not detected.

\subsection{FAAs Profiles in Mushrooms}

The FAA content in Pleurotus mushrooms is presented in Table 3. On a dry weight basis, the most abundant FAAs in P. ostreatus were glutamine $(7.8-21.69 \mathrm{mg} / \mathrm{g})$, followed by leucine $(8.59-16.45 \mathrm{mg} / \mathrm{g})$, alanine $(7.22-13.33 \mathrm{mg} / \mathrm{g})$, valine $(4.24-9.49 \mathrm{mg} / \mathrm{g})$, glutamic acid $(4.81-7.84 \mathrm{mg} / \mathrm{g})$ and serine $(3.93-8.83 \mathrm{mg} / \mathrm{g})$. The same FAAs, but in a different order, predominated in P. eryngii, i.e., leucine $(5.11-11.24 \mathrm{mg} / \mathrm{g})$, followed by alanine $(4.74-8.54 \mathrm{mg} / \mathrm{g})$, glutamine $(3.35-8.28 \mathrm{mg} / \mathrm{g})$, valine $(3.24-6.24 \mathrm{mg} / \mathrm{g})$, serine $(3.30-5.97 \mathrm{mg} / \mathrm{g})$ and glutamic acid $(3.22-5.73 \mathrm{mg} / \mathrm{g})$. Finally, leucine $(2.24-8.29 \mathrm{mg} / \mathrm{g})$ and alanine $(2.82-7.53 \mathrm{mg} / \mathrm{g})$ were the most abundant FAAs in P. nebrodensis, followed by glutamine $(0.84-7.02 \mathrm{mg} / \mathrm{g})$, glutamic acid $(2.07-4.59 \mathrm{mg} / \mathrm{g})$, serine $(0.91-4.19 \mathrm{mg} / \mathrm{g})$ and valine $(1.05-3.98 \mathrm{mg} / \mathrm{g})$. Among the species studied, $P$. nebrodensis presented the lower concentrations in most FAAs. 
Table 3. Free amino acid and crude protein contents ( $\mathrm{mg} / \mathrm{g} \mathrm{dw})$ in mushrooms of Pleurotus ostreatus, P. eryngii and P. nebrodensis produced on three cultivation substrates.

\begin{tabular}{|c|c|c|c|c|c|c|c|}
\hline \multirow{2}{*}{ Amino Acid } & \multirow{2}{*}{ Substrate } & \multicolumn{2}{|c|}{ P. ostreatus } & \multicolumn{2}{|c|}{ P. eryngii } & \multicolumn{2}{|c|}{ P. nebrodensis } \\
\hline & & LGAM 14 & LGAM 11 & UPA 12 & LGAM 212 & UPA 6 & LGAM 162 \\
\hline \multirow{3}{*}{ Alanine } & WS & $7.22 \pm 1.10 \mathrm{a}$ & $9.77 \pm 2.29 a$ & $4.74 \pm 0.32 \mathrm{a}$ & $7.27 \pm 1.08 \mathrm{a}$ & $2.82 \pm 0.19 \mathrm{a}$ & $7.20 \pm 1.47$ \\
\hline & GM & $10.34 \pm 2.31 \mathrm{ab}$ & $13.33 \pm 2.71 \mathrm{a}$ & $8.26 \pm 1.11 b$ & $8.54 \pm 1.60 \mathrm{a}$ & $4.27 \pm 0.69 \mathrm{a}$ & $7.53 \pm 3.49$ \\
\hline & OL & $11.72 \pm 2.69 \mathrm{~b}$ & $10.42 \pm 3.83 \mathrm{a}$ & $4.74 \pm 1.99 \mathrm{a}$ & $7.61 \pm 1.34 \mathrm{a}$ & $4.08 \pm 1.04 \mathrm{a}$ & $*$ \\
\hline \multirow{3}{*}{ Glycine } & WS & $1.03 \pm 0.05 \mathrm{a}$ & $1.94 \pm 0.97 \mathrm{a}$ & $1.03 \pm 0.10 \mathrm{a}$ & $1.21 \pm 0.56 \mathrm{a}$ & $0.29 \pm 0.04 \mathrm{a}$ & $1.51 \pm 0.17$ \\
\hline & GM & $1.85 \pm 0.20 \mathrm{a}$ & $2.99 \pm 0.35 \mathrm{a}$ & $1.88 \pm 0.18 b$ & $1.65 \pm 0.11 \mathrm{a}$ & $0.73 \pm 0.19 \mathrm{~b}$ & $1.61 \pm 0.55$ \\
\hline & OL & $3.29 \pm 1.13 b$ & $2.12 \pm 0.82 \mathrm{a}$ & $0.98 \pm 0.41 \mathrm{a}$ & $1.45 \pm 0.10 \mathrm{a}$ & $0.50 \pm 0.06 \mathrm{ab}$ & $*$ \\
\hline \multirow{3}{*}{ Valine } & WS & $4.24 \pm 0.34 \mathrm{a}$ & $6.94 \pm 2.08 \mathrm{a}$ & $3.24 \pm 0.12 \mathrm{a}$ & $4.81 \pm 1.12 \mathrm{a}$ & $1.05 \pm 0.14 \mathrm{a}$ & $3.97 \pm 0.61$ \\
\hline & GM & $6.94 \pm 0.84 \mathrm{ab}$ & $9.49 \pm 1.05 a$ & $5.26 \pm 0.56 b$ & $6.24 \pm 0.53 a$ & $1.76 \pm 0.80 \mathrm{a}$ & $3.98 \pm 1.54$ \\
\hline & OL & $8.44 \pm 2.19 \mathrm{~b}$ & $7.13 \pm 2.01 \mathrm{a}$ & $3.35 \pm 1.25 \mathrm{a}$ & $5.59 \pm 0.83 \mathrm{a}$ & $1.56 \pm 0.26 \mathrm{a}$ & * \\
\hline \multirow{3}{*}{ Leucine } & WS & $8.59 \pm 1.32 \mathrm{a}$ & $12.24 \pm 3.27 \mathrm{a}$ & $5.11 \pm 0.50 \mathrm{a}$ & $8.88 \pm 1.81 \mathrm{a}$ & $2.24 \pm 0.15 \mathrm{a}$ & $8.29 \pm 1.89$ \\
\hline & GM & $12.31 \pm 2.50 \mathrm{a}$ & $16.45 \pm 2.33 \mathrm{a}$ & $8.81 \pm 1.11 \mathrm{a}$ & $11.24 \pm 1.51 \mathrm{a}$ & $4.51 \pm 1.22 \mathrm{~b}$ & $7.81 \pm 3.37$ \\
\hline & OL & $9.66 \pm 8.19 \mathrm{a}$ & $9.95 \pm 6.70 \mathrm{a}$ & $7.30 \pm 3.07 \mathrm{a}$ & $10.10 \pm 1.84 \mathrm{a}$ & $4.34 \pm 1.10 \mathrm{~b}$ & $*$ \\
\hline \multirow{3}{*}{ Isoleucine } & WS & $2.80 \pm 0.29 \mathrm{a}$ & $4.13 \pm 0.96 \mathrm{a}$ & $2.15 \pm 0.06 \mathrm{a}$ & $3.15 \pm 0.77 \mathrm{a}$ & $0.67 \pm 0.03 \mathrm{a}$ & $2.81 \pm 0.53$ \\
\hline & GM & $4.35 \pm 0.66 \mathrm{ab}$ & $5.79 \pm 0.81 \mathrm{a}$ & $3.40 \pm 0.33 \mathrm{a}$ & $4.13 \pm 0.28 \mathrm{a}$ & $1.25 \pm 0.54 \mathrm{a}$ & $2.70 \pm 1.07$ \\
\hline & OL & $5.09 \pm 1.21 \mathrm{~b}$ & $4.38 \pm 1.29 \mathrm{a}$ & $2.32 \pm 0.92 \mathrm{a}$ & $3.62 \pm 0.48 \mathrm{a}$ & $1.09 \pm 0.24 \mathrm{a}$ & $*$ \\
\hline \multirow{3}{*}{ Threonine } & WS & $2.29 \pm 0.13 \mathrm{a}$ & $3.96 \pm 1.56 \mathrm{a}$ & $1.93 \pm 0.06 \mathrm{a}$ & $2.85 \pm 0.87 \mathrm{a}$ & $0.61 \pm 0.06 \mathrm{a}$ & $2.45 \pm 0.31$ \\
\hline & GM & $3.83 \pm 0.40 \mathrm{ab}$ & $5.65 \pm 0.65 \mathrm{a}$ & $3.31 \pm 0.26 b$ & $3.68 \pm 0.00 \mathrm{a}$ & $1.17 \pm 0.44 \mathrm{a}$ & $2.47 \pm 0.93$ \\
\hline & OL & $5.23 \pm 1.27 \mathrm{~b}$ & $4.19 \pm 1.08 \mathrm{a}$ & $1.93 \pm 0.77 \mathrm{a}$ & $3.22 \pm 0.33 \mathrm{a}$ & $1.02 \pm 0.20 \mathrm{a}$ & * \\
\hline \multirow{3}{*}{ Serine } & WS & $3.93 \pm 0.14 \mathrm{a}$ & $6.17 \pm 2.57 \mathrm{a}$ & $3.30 \pm 0.24 \mathrm{a}$ & $4.81 \pm 1.62 \mathrm{a}$ & $0.91 \pm 0.21 \mathrm{a}$ & $4.17 \pm 0.31$ \\
\hline & GM & $6.38 \pm 0.50 \mathrm{~b}$ & $8.81 \pm 0.32 \mathrm{a}$ & $5.77 \pm 0.64 b$ & $5.97 \pm 0.37 \mathrm{a}$ & $2.13 \pm 0.60 \mathrm{~b}$ & $4.19 \pm 1.37$ \\
\hline & OL & $8.83 \pm 1.29 c$ & $6.95 \pm 1.81 \mathrm{a}$ & $3.34 \pm 1.29 \mathrm{a}$ & $5.11 \pm 0.35 \mathrm{a}$ & $1.84 \pm 0.24 \mathrm{~b}$ & $*$ \\
\hline \multirow{3}{*}{ Proline } & WS & $1.21 \pm 0.06 \mathrm{a}$ & $2.30 \pm 1.22 \mathrm{a}$ & $1.04 \pm 0.09 \mathrm{a}$ & $1.22 \pm 0.57 \mathrm{a}$ & $0.55 \pm 0.06 \mathrm{a}$ & $1.37 \pm 0.15$ \\
\hline & GM & $2.19 \pm 0.25 \mathrm{a}$ & $3.77 \pm 0.47 \mathrm{a}$ & $2.00 \pm 0.26 b$ & $1.67 \pm 0.02 \mathrm{a}$ & $0.43 \pm 0.20 \mathrm{a}$ & $1.35 \pm 0.44$ \\
\hline & OL & $4.22 \pm 1.59 \mathrm{~b}$ & $2.69 \pm 1.37 a$ & $0.88 \pm 0.31 \mathrm{a}$ & $1.57 \pm 0.23 \mathrm{a}$ & $0.37 \pm 0.06 \mathrm{a}$ & $*$ \\
\hline \multirow{3}{*}{ Asparagine } & WS & $1.75 \pm 0.10 \mathrm{a}$ & $2.82 \pm 1.55 \mathrm{a}$ & $1.18 \pm 0.06 \mathrm{a}$ & $1.77 \pm 0.65 \mathrm{a}$ & $0.40 \pm 0.05 \mathrm{a}$ & $1.63 \pm 0.14$ \\
\hline & GM & $3.02 \pm 0.35 b$ & $4.52 \pm 0.68 \mathrm{a}$ & $2.19 \pm 0.23 b$ & $2.26 \pm 0.01 \mathrm{a}$ & $0.74 \pm 0.24 \mathrm{~b}$ & $1.57 \pm 0.52$ \\
\hline & OL & $4.39 \pm 1.03 c$ & $3.25 \pm 1.25 \mathrm{a}$ & $1.22 \pm 0.49 \mathrm{a}$ & $1.95 \pm 0.20 \mathrm{a}$ & $0.70 \pm 0.10 \mathrm{ab}$ & * \\
\hline \multirow{3}{*}{ Thioproline } & WS & $2.48 \pm 0.24 \mathrm{a}$ & $2.10 \pm 0.38 \mathrm{a}$ & $0.82 \pm 0.43 \mathrm{a}$ & $0.59 \pm 0.44 \mathrm{a}$ & $0.71 \pm 0.27 \mathrm{a}$ & $0.75 \pm 0.11$ \\
\hline & GM & $3.57 \pm 0.75 \mathrm{a}$ & $2.93 \pm 0.93 a$ & $0.93 \pm 0.30 \mathrm{a}$ & $1.12 \pm 0.03 \mathrm{a}$ & $2.69 \pm 0.30 \mathrm{~b}$ & $1.60 \pm 0.80$ \\
\hline & OL & $3.31 \pm 0.84 \mathrm{a}$ & $3.17 \pm 2.14 \mathrm{a}$ & $1.17 \pm 0.78 \mathrm{a}$ & $1.02 \pm 0.78 \mathrm{a}$ & $1.97 \pm 0.46 \mathrm{c}$ & $*$ \\
\hline \multirow{3}{*}{ Aspartic acid } & WS & $2.51 \pm 0.09 \mathrm{a}$ & $2.20 \pm 0.03 a$ & $0.98 \pm 0.26 a$ & $0.81 \pm 0.57 \mathrm{a}$ & $0.76 \pm 0.19 \mathrm{a}$ & $0.81 \pm 0.10$ \\
\hline & GM & $3.51 \pm 0.48 \mathrm{~b}$ & $2.65 \pm 0.80 \mathrm{a}$ & $1.14 \pm 0.28 \mathrm{a}$ & $1.06 \pm 0.12 \mathrm{a}$ & $2.59 \pm 0.40 \mathrm{~b}$ & $1.69 \pm 0.62$ \\
\hline & $\mathrm{OL}$ & $3.55 \pm 0.62 \mathrm{~b}$ & $3.32 \pm 2.12 \mathrm{a}$ & $1.22 \pm 0.69 \mathrm{a}$ & $1.27 \pm 0.85 \mathrm{a}$ & $1.94 \pm 0.52 \mathrm{~b}$ & $*$ \\
\hline
\end{tabular}


Table 3. Cont

\begin{tabular}{|c|c|c|c|c|c|c|c|}
\hline \multirow{2}{*}{ Amino Acid } & \multirow{2}{*}{ Substrate } & \multicolumn{2}{|c|}{ P. ostreatus } & \multicolumn{2}{|c|}{ P. eryngii } & \multicolumn{2}{|c|}{ P. nebrodensis } \\
\hline & & LGAM 14 & LGAM 11 & UPA 12 & LGAM 212 & UPA 6 & LGAM 162 \\
\hline \multirow{3}{*}{ Methionine } & WS & $1.14 \pm 0.12 \mathrm{a}$ & $1.86 \pm 0.68 \mathrm{a}$ & $0.66 \pm 0.21 \mathrm{a}$ & $1.36 \pm 0.31 \mathrm{a}$ & $0.09 \pm 0.01 \mathrm{a}$ & $1.31 \pm 0.23$ \\
\hline & GM & $1.66 \pm 0.21 \mathrm{ab}$ & $2.47 \pm 0.14 \mathrm{a}$ & $1.08 \pm 0.04 \mathrm{a}$ & $1.62 \pm 0.08 \mathrm{a}$ & $0.58 \pm 0.19 \mathrm{~b}$ & $1.15 \pm 0.42$ \\
\hline & $\mathrm{OL}$ & $2.10 \pm 0.57 \mathrm{~b}$ & $1.93 \pm 0.42 \mathrm{a}$ & $0.90 \pm 0.31 \mathrm{a}$ & $1.50 \pm 0.23 \mathrm{a}$ & $0.51 \pm 0.10 \mathrm{~b}$ & $*$ \\
\hline \multirow{3}{*}{ Hydroxyproline } & WS & $0.39 \pm 0.04 \mathrm{a}$ & $0.48 \pm 0.15 a$ & $0.22 \pm 0.08 \mathrm{a}$ & $0.40 \pm 0.09 a$ & $0.11 \pm 0.10 \mathrm{a}$ & $0.34 \pm 0.02$ \\
\hline & GM & $0.60 \pm 0.09 \mathrm{~b}$ & $0.71 \pm 0.12 \mathrm{a}$ & $0.44 \pm 0.08 \mathrm{~b}$ & $0.44 \pm 0.04 \mathrm{a}$ & $0.25 \pm 0.08 \mathrm{a}$ & $0.36 \pm 0.09$ \\
\hline & OL & $0.66 \pm 0.11 \mathrm{~b}$ & $0.58 \pm 0.13 \mathrm{a}$ & $0.25 \pm 0.07 \mathrm{a}$ & $0.38 \pm 0.05 \mathrm{a}$ & $0.24 \pm 0.01 \mathrm{a}$ & $*$ \\
\hline \multirow{3}{*}{ Glutamic acid } & WS & $4.81 \pm 0.92 \mathrm{a}$ & $5.68 \pm 1.19 \mathrm{a}$ & $3.22 \pm 0.48 \mathrm{a}$ & $4.92 \pm 0.63 \mathrm{a}$ & $2.07 \pm 0.09 \mathrm{a}$ & $4.42 \pm 1.21$ \\
\hline & GM & $6.76 \pm 2.08 \mathrm{a}$ & $7.84 \pm 2.44 a$ & $5.29 \pm 0.70 \mathrm{~b}$ & $5.73 \pm 1.35 \mathrm{a}$ & $3.58 \pm 0.62 \mathrm{a}$ & $4.59 \pm 2.15$ \\
\hline & $\mathrm{OL}$ & $7.39 \pm 2.32 \mathrm{a}$ & $6.76 \pm 2.55 \mathrm{a}$ & $3.60 \pm 1.47 \mathrm{ab}$ & $4.77 \pm 0.81 \mathrm{a}$ & $3.46 \pm 1.18 \mathrm{a}$ & $*$ \\
\hline \multirow{3}{*}{ Phenylalanine } & WS & $2.95 \pm 0.24 \mathrm{a}$ & $4.30 \pm 1.51 \mathrm{a}$ & $1.71 \pm 0.20 \mathrm{a}$ & $2.94 \pm 0.71 \mathrm{a}$ & $0.97 \pm 0.03 \mathrm{a}$ & $3.05 \pm 0.54$ \\
\hline & GM & $4.14 \pm 0.55 \mathrm{ab}$ & $6.01 \pm 0.11 \mathrm{a}$ & $2.91 \pm 0.19 \mathrm{~b}$ & $3.57 \pm 0.01 \mathrm{a}$ & $1.74 \pm 0.41 \mathrm{~b}$ & $2.81 \pm 1.10$ \\
\hline & OL & $5.33 \pm 1.16 \mathrm{~b}$ & $4.68 \pm 1.45 \mathrm{a}$ & $2.27 \pm 0.83 \mathrm{ab}$ & $3.31 \pm 0.57 \mathrm{a}$ & $1.98 \pm 0.47 \mathrm{~b}$ & $*$ \\
\hline \multirow{3}{*}{ Glutamine } & WS & $7.80 \pm 0.69 a$ & $10.04 \pm 6.97 \mathrm{a}$ & $3.35 \pm 0.82 \mathrm{a}$ & $7.19 \pm 0.87 \mathrm{a}$ & $0.84 \pm 0.61 \mathrm{a}$ & $7.02 \pm 0.69$ \\
\hline & GM & $14.08 \pm 2.32 b$ & $21.69 \pm 6.93 a$ & $8.28 \pm 1.61 b$ & $7.52 \pm 1.04 \mathrm{a}$ & $4.22 \pm 0.69 \mathrm{~b}$ & $6.99 \pm 1.17$ \\
\hline & OL & $20.03 \pm 1.09 c$ & $13.06 \pm 8.46 \mathrm{a}$ & $4.66 \pm 2.40 \mathrm{a}$ & $6.96 \pm 1.74 \mathrm{a}$ & $6.42 \pm 1.23 \mathrm{c}$ & * \\
\hline \multirow{3}{*}{ Ornithine } & WS & $0.65 \pm 0.08 \mathrm{a}$ & $0.63 \pm 0.24 \mathrm{a}$ & $0.65 \pm 0.04 b$ & $0.36 \pm 0.08 \mathrm{a}$ & $0.42 \pm 0.01 \mathrm{a}$ & $1.51 \pm 0.29$ \\
\hline & GM & $0.93 \pm 0.15 b$ & $0.90 \pm 0.25 \mathrm{a}$ & $0.82 \pm 0.09 b$ & $0.50 \pm 0.19 a$ & $0.76 \pm 0.08 b$ & $1.63 \pm 0.67$ \\
\hline & $\mathrm{OL}$ & $1.10 \pm 0.14 b$ & $0.56 \pm 0.28 \mathrm{a}$ & $0.31 \pm 0.14 \mathrm{a}$ & $0.43 \pm 0.09 \mathrm{a}$ & $0.32 \pm 0.12 \mathrm{a}$ & $*$ \\
\hline \multirow{3}{*}{ Lysine } & WS & $2.47 \pm 0.27 \mathrm{a}$ & $3.23 \pm 0.83 a$ & $1.83 \pm 0.09 \mathrm{a}$ & $2.77 \pm 0.32 \mathrm{a}$ & $0.53 \pm 0.03 \mathrm{a}$ & $2.79 \pm 0.49$ \\
\hline & GM & $3.33 \pm 0.78 \mathrm{a}$ & $4.29 \pm 0.67 \mathrm{a}$ & $2.77 \pm 0.41 \mathrm{a}$ & $3.42 \pm 0.45 \mathrm{a}$ & $1.36 \pm 0.44 b$ & $2.61 \pm 1.02$ \\
\hline & OL & $4.20 \pm 1.30 \mathrm{a}$ & $3.59 \pm 1.10 \mathrm{a}$ & $2.21 \pm 1.02 \mathrm{a}$ & $2.96 \pm 0.51 \mathrm{a}$ & $1.44 \pm 0.30 \mathrm{~b}$ & * \\
\hline \multirow{3}{*}{ Histidine } & WS & $0.88 \pm 0.17 \mathrm{a}$ & $1.67 \pm 1.24 \mathrm{a}$ & $0.52 \pm 0.07 \mathrm{a}$ & $0.88 \pm 0.50 \mathrm{a}$ & $0.10 \pm 0.05 \mathrm{a}$ & $0.98 \pm 0.21$ \\
\hline & GM & $1.63 \pm 0.27 \mathrm{ab}$ & $2.59 \pm 0.57 \mathrm{a}$ & $1.14 \pm 0.26 \mathrm{~b}$ & $1.14 \pm 0.33 \mathrm{a}$ & $0.32 \pm 0.21 \mathrm{a}$ & $0.86 \pm 0.21$ \\
\hline & OL & $2.46 \pm 1.03 \mathrm{~b}$ & $1.66 \pm 0.66 \mathrm{a}$ & $0.63 \pm 0.20 \mathrm{a}$ & $1.04 \pm 0.30 \mathrm{a}$ & $0.33 \pm 0.06 \mathrm{a}$ & $*$ \\
\hline \multirow{3}{*}{ Tyrosine } & WS & $2.66 \pm 0.08 \mathrm{a}$ & $4.25 \pm 1.73 \mathrm{a}$ & $1.54 \pm 0.12 \mathrm{a}$ & $2.59 \pm 0.62 \mathrm{a}$ & $0.95 \pm 0.13 \mathrm{a}$ & $3.05 \pm 0.46$ \\
\hline & GM & $3.99 \pm 0.44 a b$ & $5.93 \pm 0.33 a$ & $2.67 \pm 0.24 b$ & $3.18 \pm 0.23 \mathrm{a}$ & $1.70 \pm 0.42 b$ & $2.81 \pm 1.04$ \\
\hline & $\mathrm{OL}$ & $4.96 \pm 1.08 \mathrm{~b}$ & $4.34 \pm 1.42 \mathrm{a}$ & $1.95 \pm 0.70 \mathrm{ab}$ & $3.11 \pm 0.54 \mathrm{a}$ & $1.40 \pm 0.23 \mathrm{ab}$ & $*$ \\
\hline
\end{tabular}


Table 3. Cont

\begin{tabular}{|c|c|c|c|c|c|c|c|}
\hline \multirow{2}{*}{ Amino Acid } & \multirow{2}{*}{ Substrate } & \multicolumn{2}{|c|}{ P. ostreatus } & \multicolumn{2}{|c|}{ P. eryngii } & \multicolumn{2}{|c|}{ P. nebrodensis } \\
\hline & & LGAM 14 & LGAM 11 & UPA 12 & LGAM 212 & UPA 6 & LGAM 162 \\
\hline \multirow{3}{*}{ Tryptophan } & WS & $1.07 \pm 0.12 \mathrm{a}$ & $0.81 \pm 0.71 \mathrm{a}$ & $0.59 \pm 0.15 a$ & $1.22 \pm 0.68 \mathrm{a}$ & $0.18 \pm 0.04 a$ & $1.16 \pm 0.34$ \\
\hline & GM & $1.80 \pm 0.33 a$ & $1.76 \pm 0.00 \mathrm{a}$ & $1.14 \pm 0.09 \mathrm{~b}$ & $0.55 \pm 0.78 \mathrm{a}$ & $0.43 \pm 0.14 b$ & $1.01 \pm 0.33$ \\
\hline & OL & $1.70 \pm 0.00 \mathrm{a}$ & $1.44 \pm 0.22 \mathrm{a}$ & $0.76 \pm 0.28 a$ & $0.76 \pm 0.66 \mathrm{a}$ & $0.42 \pm 0.09 b$ & $*$ \\
\hline \multirow{3}{*}{$\begin{array}{c}\gamma \text {-Aminobutyric } \\
\text { acid (GABA) }\end{array}$} & WS & $0.21 \pm 0.01 \mathrm{a}$ & $0.31 \pm 0.20 \mathrm{a}$ & $0.08 \pm 0.05 a$ & $0.18 \pm 0.13 \mathrm{a}$ & $0.09 \pm 0.03 a$ & $0.56 \pm 0.26$ \\
\hline & GM & $0.43 \pm 0.21 \mathrm{a}$ & $0.70 \pm 0.41 \mathrm{a}$ & $0.38 \pm 0.12 b$ & $0.18 \pm 0.03 \mathrm{a}$ & $0.18 \pm 0.05 \mathrm{a}$ & $0.86 \pm 0.37$ \\
\hline & OL & $0.46 \pm 0.21 \mathrm{a}$ & $0.35 \pm 0.21 \mathrm{a}$ & $0.06 \pm 0.02 \mathrm{a}$ & $0.23 \pm 0.08 \mathrm{a}$ & $0.36 \pm 0.12 b$ & $*$ \\
\hline \multirow{3}{*}{$\begin{array}{l}\text { Total free } \\
\text { amino acids }\end{array}$} & WS & $63.10 \pm 4.22 \mathrm{a}$ & $87.84 \pm 29.53 a$ & $62.19 \pm 13.43 a$ & $39.91 \pm 1.58 \mathrm{a}$ & $17.37 \pm 1.48 \mathrm{a}$ & $61.18 \pm 9.42$ \\
\hline & GM & $97.03 \pm 14.44 b$ & $130.12 \pm 17.16 a$ & $75.44 \pm 4.42 \mathrm{a}$ & $69.86 \pm 5.81 b$ & $37.42 \pm 7.09 \mathrm{~b}$ & $62.16 \pm 22.76$ \\
\hline & $\mathrm{OL}$ & $116.98 \pm 19.46 b$ & $96.05 \pm 31.79 \mathrm{a}$ & $67.89 \pm 8.88 \mathrm{a}$ & $46.03 \pm 19.17 \mathrm{a}$ & $36.30 \pm 7.68 b$ & * \\
\hline \multirow{3}{*}{ Crude protein } & WS & $164.07 \pm 1.65 \mathrm{a}$ & $177.36 \pm 3.55 a$ & $154.63 \pm 9.25 \mathrm{a}$ & $144.70 \pm 2.90 b$ & $121.10 \pm 1.20 \mathrm{a}$ & $175.20 \pm 5.26$ \\
\hline & GM & $221.18 \pm 11.05 b$ & $284.77 \pm 2.85 b$ & $187.83 \pm 1.85 b$ & $179.60 \pm 5.40 \mathrm{c}$ & $175.23 \pm 8.73 b$ & $172.24 \pm 10.33$ \\
\hline & OL & $293.20 \pm 17.60 \mathrm{c}$ & $299.20 \pm 9.00 \mathrm{c}$ & $167.23 \pm 8.35 \mathrm{a}$ & $130.77 \pm 7.84 \mathrm{a}$ & $130.50 \pm 5.20 \mathrm{a}$ & * \\
\hline
\end{tabular}

* Results are presented as means \pm standard deviation $(n=3)$. Lack of letters in common indicates statistically significant differences (Duncan's t-Test. $p<0.05)$ in comparisons of treatment means between different substrates. Abbreviations: $\mathrm{dw}$, dry weight; WS, wheat straw; GM, wheat straw with grape marc (1:1 w/w); OL, olive leaves with olive mill wastes (3:1 $w / w$ ratio); *, no mushroom production. 
In literature, glutamic acid, alanine, arginine and threonine have been reported among the predominating FAAs in Pleurotus species cultivated on several lignocellulosic wastes, followed in decreasing frequency by leucine, aspartic acid, valine and serine $[12,15,23]$. The same group of amino acids, with glutamic acid present in higher amounts, also predominated in other mushroom species, such as Agaricus brasiliensis, Lentinula edodes, Hericium erinaceus, Cordyceps militaris, Grifola frondosa, Coprinus comatus, Flammulina velutipes and Tremella fuciformis [24]. Glutamic acid, followed by alanine and aspartic acid predominated also in Agaricus bisporus and Lentinula edodes samples [25]. Deviations from the findings of the present study can be explained by differences in the composition of the substrates used and by the species/strain examined.

\subsubsection{Protein and Total FAAs Content}

Total FAAs and protein content of the mushrooms studied are shown in Table 3. Crude protein content ranged from $121.1 \mathrm{mg} / \mathrm{g} \mathrm{dw}$ in P. nebrodensis UPA 6 grown on WS to 293.2 and $299.2 \mathrm{mg} / \mathrm{g}$ $\mathrm{dw}$ in P. ostreatus LGAM 11 cultivated on OL and GM, respectively. On average, the crude protein content in P. ostreatus mushrooms was notably higher than in P. eryngii and P. nebrodensis fruitbodies (Table 3). With regard to substrates, P. ostreatus mushrooms cultivated on OL presented the highest protein content, followed by those grown on GM and WS. The other two species studied presented a different pattern, with their protein values decreasing in the order $\mathrm{GM}>\mathrm{OL}>$ WS.

Total FAAs content ranged from $17.37 \mathrm{mg} / \mathrm{g} \mathrm{dw}$ in P. nebrodensis UPA 6 produced on WS to $130.12 \mathrm{mg} / \mathrm{g} \mathrm{dw}$ in P. ostreatus LGAM 11 cultivated on GM, following similar patterns of distribution to those of crude protein. Total FAAs corresponded (in average) to $41.6,37.1$ and $28.3 \%$ of total protein in P. ostreatus, P. eryngii and P. nebrodensis, respectively; the respective fractions were $34.2,37.7$ and $35.1 \%$ for mushrooms produced on WS, GM and OL (Table 3). Among the species studied, P. ostreatus exhibited the highest FAAs content, followed by P. eryngii and P. nebrodensis regardless of the substrate used (Table 3). The outcome of this study is in agreement with previously reported results evidencing that $P$. ostreatus mushrooms present higher FAAs content compared to P. eryngii $[25,26]$.

Regarding the effect of cultivation substrate on mushrooms' FAAs content, the use of GM substrate resulted in a statistically significant increase of FAAs content in the produced mushrooms when compared to the control (WS) for all the species studied, while in the case of cultivation on OL, differences were observed only in P. ostreatus (Figure 1). Therefore, it appears that the use of GM in Pleurotus cultivation substrates leads to enhanced FAAs production. The addition of olive mill wastes $(\mathrm{OL})$, although resulting in increased FAAs content, inhibited the growth of certain Pleurotus strains, as has been previously shown [8]. 

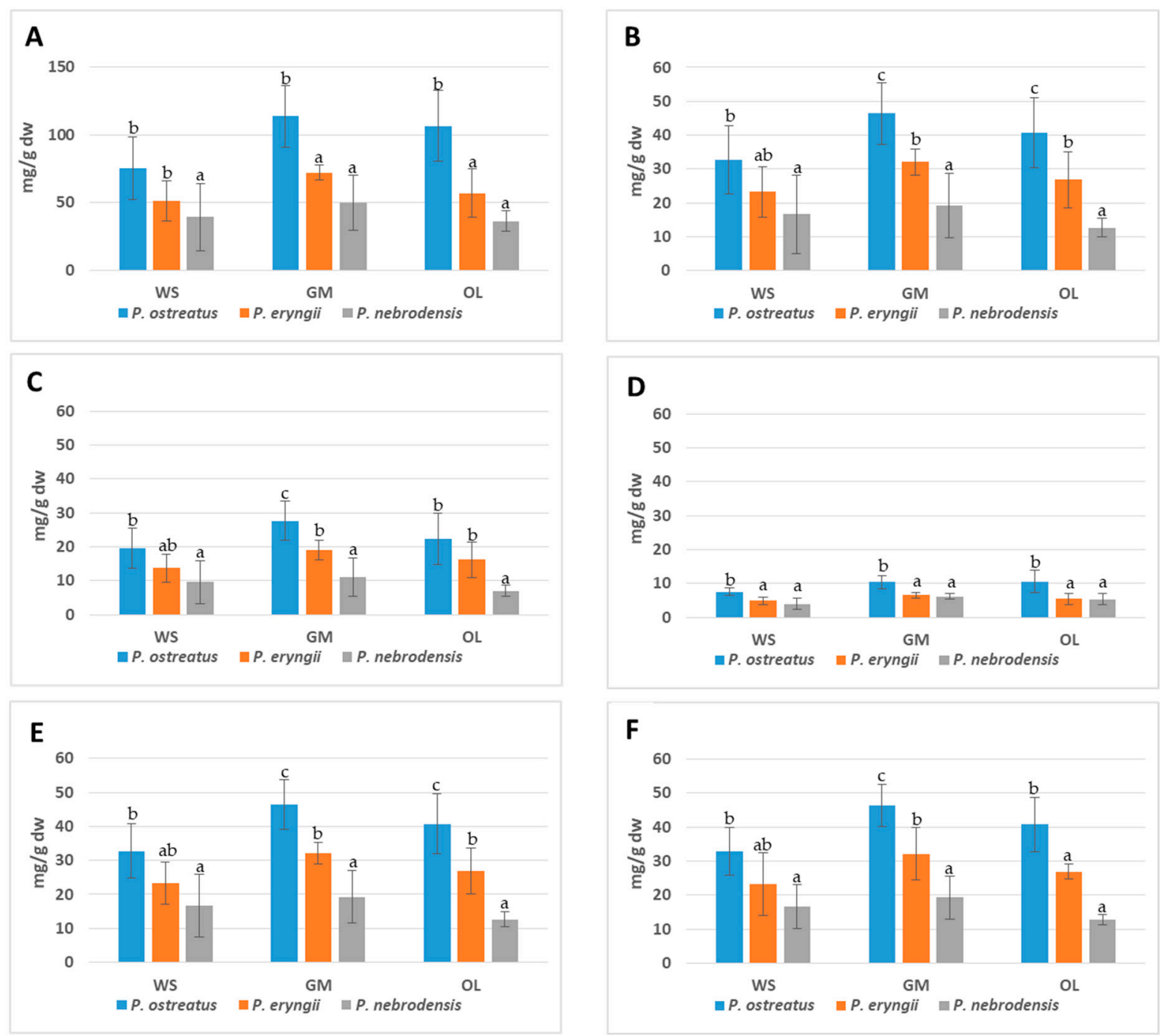

Figure 1. Total and individual groups of free amino acids in Pleurotus mushrooms, compared by species in each substrate. (A) Total Amino Acids, (B) Essential Amino Acids, (C) Branched Chain Amino Acids; (D) Monosodium Glutamate (MSG)-like Amino Acids, (E) Bitter Taste Amino Acids, (F) Sweet Taste Amino Acids. Lack of letters in common denotes statistically significant differences in comparisons among species in each substrate by Duncan's multiple comparison test at $p<0.05$. Essential amino acids, Thr + Val + Met + Ile + Leu + Phe + Lys + His + Trp; BCAA Branched chain amino acids, Val + Ile + Leu; MSG-like, monosodium glutamate-like, Asp + Glu; Bitter, Val + Met + Ile + Leu + Phe + His + Trp; Sweet, Thr + Ser + Gly + Ala + Pro.

Previous studies on total FAAs in Pleurotus mushrooms exhibit wide fluctuations, with reported values ranging from 3.3 to $192 \mathrm{mg} / \mathrm{g}$ dw [12,15,23,26-28]. Large variations of total FAAs values have been also reported for other widely cultivated mushroom species, e.g., 10.1-55.7 mg/g dw for L. edodes [15,24-26,29], 18.8-168.4 mg/g dw for A. bisporus [24-26] and 19.2-147.1 mg/g dw for F. velutipes $[15,24-26]$.

Such fluctuations are not surprising given that, besides the influence of genetic factors (i.e., species and strains), mushrooms composition is additionally affected by the stage of development, the nature of pre- and post-harvest treatments and the type of growth substrate [30]. Additionally, different methods of FAAs isolation and quantification may result in such inconsistencies. The values of FAAs determined in the present work are among the highest reported for Pleurotus mushrooms. 


\subsubsection{Essential FAAs}

Mushrooms usually contain all the essential FAAs, which comprise $25-40 \%$ of total FAAs content [31]. In the present study, all essential FAAs were detected in the samples examined, representing in average the 41,46 and $38 \%$ of total FAAs in P. ostreatus, P. eryngii and P. nebrodensis mushrooms, respectively; their relative contents were significantly higher than those measured in the cultivation substrates, i.e., 19, 22 and 22\% of total FAAs in WS, GM and OL, respectively (Table 2). The essential FAAs followed similar distribution patterns to those of total FAAs, and hence, the highest values were noted in P. ostreatus mushrooms ( 39.13 and $53.33 \mathrm{mg} / \mathrm{g}$ in WS and GM substrates by LGAM 11 , and $43.08 \mathrm{mg} / \mathrm{g}$ in OL by LGAM 14) (Supplementary Table S2), whereas the lowest concentrations were recorded in fruitbodies of P. nebrodensis UPA 6 (6.43 to $13.13 \mathrm{mg} / \mathrm{g} \mathrm{dw}$ ). Literature data for essential FAAs in cultivated Pleurotus mushrooms presented wide fluctuations with reported values ranging from $1.76 \mathrm{mg} / \mathrm{g}$ in P. eryngii to $78.2 \mathrm{mg} / \mathrm{g}$ dw in P. ostreatus [12,15,23,32-34]. Among the essential FAAs of the Pleurotus species and strains studied, leucine predominated, followed by valine, isoleucine, threonine, phenylalanine and lysine (Table 2). In agreement with our findings, leucine together with valine and lysine were reported to predominate among the essential FAAs in three Pleurotus species grown on wheat stalk [32], and in P. ostreatus grown on several lignocellulosic agro wastes [35]. When poplar sawdust with rice bran was used as cultivation substrate, threonine predominated among the essential FAAs in five out of six Pleurotus species, with leucine predominating only in P. djamor [28]. In addition, studies on total AAs also reported leucine to be the most abundant essential amino acid in P. ostreatus powder [36], in wild and cultivated "P. sajor-caju" [37], in seven strains of P. ostreatus grown on wheat straw with sugar beet [30] and in three out of four commercial Pleurotus species [27].

\subsubsection{Branched Chain Amino Acids, GABA and Ornithine}

BCAAs are necessary for the synthesis of proteins and consequently for the production of immunoglobulins, cytokines and their receptors. Thus, BCAAs availability in the diet is of importance since they also exhibit a significant immunoregulating role [38], which is already well established for mushrooms beta-glucans $[39,40]$. In the present study the highest concentrations of free BCAAs were recorded in P. ostreatus fruitbodies, followed by P. eryngii and P. nebrodensis; P. ostreatus LGAM 11 cultivated on GM demonstrated the highest value $(31.73 \mathrm{mg} / \mathrm{g} \mathrm{dw})$, while P. ostreatus LGAM 14 cultivated on OL produced mushrooms with higher amounts of BCAAs $(23.19 \mathrm{mg} / \mathrm{g} \mathrm{dw})$ than those grown on WS $(15.64 \mathrm{mg} / \mathrm{g} \mathrm{dw})$. The lowest BCAAs contents were observed in P. nebrodensis UPA 6 (3.96 to $7.52 \mathrm{mg} / \mathrm{g} \mathrm{dw}$ ). Among substrates, cultivation on GM resulted in the higher amounts of leucine, valine and isoleucine in P. eryngii UPA 12 and LGAM 212 and in P. nebrodensis UPA 6; P. ostreatus LGAM 11 cultivated on GM and P. ostreatus LGAM 14 cultivated on OL produced mushrooms with the higher valine and isoleucine contents. Values for free BCAAs content obtained herein fall within the range of $0.64-36.75 \mathrm{mg} / \mathrm{g} \mathrm{dw}$ reported in the literature for several Pleurotus species [28,32-35,41]. Regarding individual BCAAs, leucine predominated in all cases of the present study, followed by valine and isoleucine. The outcome of previous publications [32,35] are in line with our findings including reports with valine predominating over leucine [33,34,41]. On the other hand, Yin et al. [28] showed that leucine content was higher than valine's in four out of six Pleurotus species.

GABA and ornithine are two non-essential AAs with significant physiological activities. GABA is a non-protein, four carbon AA present in plants, animals and microorganisms. It participates in the Krebs cycle, and behaves as a potent neurotransmitter in the central nervous system of vertebrates by decreasing neuron activity [42]. Ornithine is a precursor in the synthesis of arginine and participates in the urea cycle. It is involved in the production of excess growth hormone and in the burn up of excess fat in the body. Moreover, ornithine's role in the immune system and liver functions is considered crucial [43].

In the present work, low amounts of GABA were measured in all mushroom and substrate samples; GABA was not detected in the WS substrate (Table 2). In mushrooms cultivated on WS, free GABA concentrations ranged from $0.08 \mathrm{mg} / \mathrm{g} \mathrm{dw}$ in P. eryngii UPA 12 to $0.56 \mathrm{mg} / \mathrm{g} \mathrm{dw}$ in P. nebrodensis 
LGAM 162. In mushrooms produced on GM, GABA concentrations varied between $0.18-0.86 \mathrm{mg} / \mathrm{g}$ $\mathrm{d} w$, with the lowest observed in P. eryngii LGAM 212 and P. nebrodensis UPA 6, and the highest in $P$. nebrodensis LGAM 162. Finally, the GABA content of mushrooms cultivated on OL ranged from 0.06 to $0.46 \mathrm{mg} / \mathrm{g} \mathrm{dw}$ in P. eryngii UPA 12 and P. ostreatus LGAM 14, respectively. Lower GABA concentrations were observed in mushrooms grown on WS compared to the other substrates, the decrement in most cases being not statistically significant. Overall, GABA concentrations ranged from 0.06 to $0.86 \mathrm{mg} / \mathrm{g}$ $\mathrm{dw}$ (Table 3). Previous studies on the GABA content in Pleurotus mushrooms reported a high variability with values ranging from 0.06 to $3.91 \mathrm{mg} / \mathrm{g} \mathrm{dw}[26,28,30,33,34]$, while the respective content in mycelia of 13 Pleurotus species was reported to range from $0.20 \mathrm{mg} / \mathrm{g} \mathrm{dw}$ in "P. florida" to $2.81 \mathrm{mg} / \mathrm{g} \mathrm{dw}$ in P. eryngii [44].

Recently, Park et al. [45] examined GABA production by adding selected AAs in liquid cultures of $L$. edodes, and observed a three-fold increase of GABA in respect to the control when the medium was supplemented with glutamic acid, whereas supplementation with alanine and glycine did not affect GABA production. The findings of this study are consistent with the fact that GABA is formed by the decarboxylation of glutamic acid or its salts [42,46]. In the substrates used in the present study, glutamic acid predominated among FAAs in WS and GM at concentrations equal to 0.155 and $0.200 \mathrm{mg} / \mathrm{g} \mathrm{dw}$, respectively, while it was lower in OL (0.064 mg/g dw; Table 2). Substrates content in free glutamic acid and crude protein (lower in WS compared to GM and OL) could partly explain the increased GABA concentrations measured in mushrooms of most strains cultivated on GM in respect to those cultivated on WS (Table 3).

Free ornithine was also detected in all mushroom and substrate samples at concentrations ranging from 0.36 to $1.51 \mathrm{mg} / \mathrm{g} \mathrm{dw}$ in P. eryngii LGAM 212 and P. nebrodensis LGAM 162 (cultivated on WS), respectively, from 0.50 to $1.63 \mathrm{mg} / \mathrm{g}$ dw in P. eryngii LGAM 212 and P. nebrodensis LGAM 162 (cultivated on GM), respectively, and from 0.31 to $1.10 \mathrm{mg} / \mathrm{g} \mathrm{dw}$ in P. eryngii UPA 12 and P. ostreatus LGAM 14 (cultivated on OL), respectively. Overall, ornithine concentrations in the present study did not exhibit any specific trend and/or correlation with substrates or species/strains. Free ornithine values of $0.23-3.80$ for P. ostreatus and $1.40-8.45 \mathrm{mg} / \mathrm{g} \mathrm{dw}$ for P. eryngii have been previously reported in mushrooms cultivated on wheat straw, poplar sawdust and rice bran, and on sugar beet with wheat straw $[26,28,30]$.

\subsubsection{Taste Attributes}

In regard to the palatability characteristics of mushrooms studied, P. ostreatus exhibited the highest concentration of bitter taste FAAs, with strain LGAM 11 cultivated on WS and GM reaching 31.95 and $43.39 \mathrm{mg} / \mathrm{g} \mathrm{dw}$ and strain LGAM 14 cultivated on OL reaching $33.65 \mathrm{mg} / \mathrm{g} \mathrm{dw}$. The lower amounts of bitter AA were measured in P. nebrodensis UPA 6, i.e., 5.29 to $10.59 \mathrm{mg} / \mathrm{g} \mathrm{dw}$ (Supplementary Table S2). In the literature, bitter FAAs content for P. ostreatus and P. eryngii were reported to range from 0.78 to $51 \mathrm{mg} / \mathrm{g} \mathrm{dw}$ and from 2.7 to $37 \mathrm{mg} / \mathrm{g} \mathrm{dw}$, respectively [12,15,23,28,32].

The distribution pattern of sweet FAAs was similar to that of bitter FAAs, with higher values obtained in P. ostreatus LGAM 11 cultivated on WS and GM (24.15 and $34.56 \mathrm{mg} / \mathrm{g} \mathrm{dw}$, respectively) and P. ostreatus LGAM 14 grown on OL $(33.28 \mathrm{mg} / \mathrm{g} \mathrm{dw})$. Lower amounts of sweet FAAs were recorded in P. nebrodensis UPA 6, i.e., 5.19 to $8.747 .82 \mathrm{mg} / \mathrm{g}$ dw (Supplementary Table S2). Sweet AAs previously reported for $P$. ostreatus ranged from $0.77 \mathrm{mg} / \mathrm{g} \mathrm{dw}$ in mushrooms cultivated on wheat and paddy straw [35], and $12.3 \mathrm{mg} / \mathrm{g} \mathrm{dw}$ in fruitbodies obtained on poplar sawdust supplemented with rice bran [28], up to $48 \mathrm{mg} / \mathrm{g} d \mathrm{w}$ in mushrooms cultivated on wheat stalks [32], or $13.8 \mathrm{mg} / \mathrm{g}$ $\mathrm{dw}$ in specimens collected in nature [41]. The respective literature data for sweet FAAs in P. eryngii mushrooms range from 1.7 to $35 \mathrm{mg} / \mathrm{g} \mathrm{dw}$ in mushrooms cultivated in commercial substrates and on wheat stalks, respectively [23,32].

Among the AAs determined, aspartic acid and glutamic acid are known to contribute to the umami taste of foodstuffs, and are characterized as monosodium glutamate-like (MSG-like) AAs [29,47,48]. In the present study the highest concentrations of MSG-like FAAs were recorded in P. ostreatus 
and the lowest in P. nebrodensis samples. Mushrooms of both P. ostreatus strains cultivated on GM and OL contained more than $10 \mathrm{mg} / \mathrm{g}$ dw of MSG-like FAAs (Figure 1; Supplementary Table S2). The lower amounts of MSG-like FAAs were observed in P. nebrodensis UPA 6 fruitbodies grown on WS, GM and OL (2.83, 6.18 and $5.40 \mathrm{mg} / \mathrm{g} \mathrm{dw}$, respectively). Mau et al. [16] ranked edible and medicinal mushrooms according to their equivalent umami concentrations and observed that, among the Pleurotus species, P. citrinopileatus exhibited the highest values followed by P. eryngii and P. ostreatus. Moreover, Mau et al. [15], classified mushrooms according to their MSG-like FAAs contents as high ( $>20 \mathrm{mg} / \mathrm{g})$, middle (5-20 mg/g) and low ( $<5 \mathrm{mg} / \mathrm{g})$. Hence, the mushrooms investigated hereby are classified as middle ( 4.2 to $10.9 \mathrm{mg} / \mathrm{g} \mathrm{dw})$, except for the P. eryngii UPA 12 fruitbodies cultivated on WS and OL, which are classified as low. Our results are in agreement with those reported in literature for MSG-like FAAs content in Pleurotus mushrooms, i.e., 0.84-48 mg/g dw [12,15,23,28,33,34].

\subsection{Principal Component Analysis}

A Principal Component Analysis (PCA) was performed on the entire FAAs profile of the three Pleurotus species in order to investigate the existence of any groupings or associations. The first two principal components explained most of the data set variance (i.e., 96.9\%), while after the projection of the first $(\mathrm{PC} 1 ; 91.1 \%)$ against the second principal component (PC2; 5.8\%), three independent clusters were formed corresponding to the data sets of P. ostreatus, P. eryngii and P. nebrodensis (with ellipses drawn at a confidence level of 0.95 ). The difference on ellipses' size indicated variations among the determined total FAAs content for each species cultivated on the three substrates. P. ostreatus was distinctly separated from P. eryngii and P. nebrodensis across PC1 ( $x$-axis), in accordance with their phylogenetic affinity [5]. Moreover, P. eryngii was distinguished from P. nebrodensis across PC2 (y-axis) (Figure 2a). The observation of the responsible loadings (Figure 2b) revealed an impact of both PCs on the grouping, particularly as regards PC1. Amino acids such as glutamine, leucine and alanine seem to dominate P. ostreatus strains, while methionine, proline, tryptophan, isoleucine and others appear to be related to $P$. eryngii and $P$. nebrodensis. On the other hand, the observation of PC2 loadings revealed a positive correlation of $P$. nebrodensis species with AAs such as glutamine, threonine, aspartic acid and proline. A positive correlation of P. eryngii species with AAs such as leucine, alanine, serine and valine was also observed across the PC2 loadings (negative values). When the analysis was conducted on the basis of the cultivation substrates used, no grouping of mushrooms was observed (Figure S1, Supplementary Material). This indicates a significant effect of different Pleurotus species on the FAAs profiles, whereas the effect of different substrates was not discernible. Recently, the application of PCA on FAAs and 5'-nucleotides of shiitake mushrooms was found suitable for the discrimination of species and geographical origins [49]. 

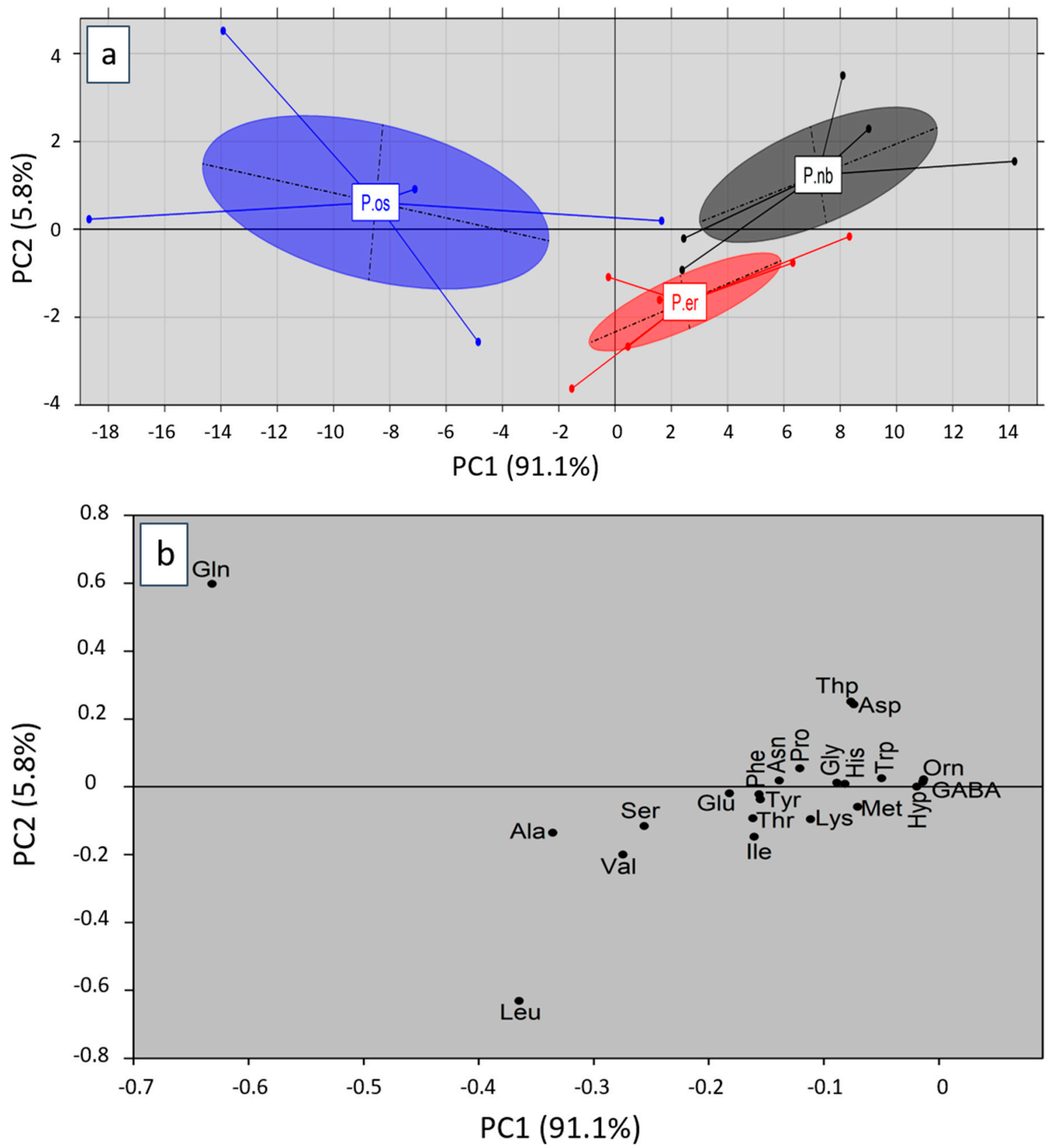

Figure 2. (a) Score plot of PCA (PC1 vs. PC2) for the discrimination among Pleurotus species (P. os, P. ostreatus; P. er, P. eryngii; P. nb, P. nebrodensis); (b) Plot with the loadings of the amino acids related to the discrimination among Pleurotus species.

\section{Materials and Methods}

\subsection{Biological Material and Mushroom Cultivation Substrates}

P. ostreatus strains LGAM 11 and LGAM 14, P. eryngii strains UPA 12 and LGAM 212 and P. nebrodensis strains UPA 6 and LGAM 162 were examined. Biological material is maintained in the Culture Collection of the Agricultural University of Athens (Laboratory of General and Agricultural Microbiology, Athens, Greece). Three mushroom cultivation substrates were used consisting of wheat straw (WS) as control, wheat straw in 1:1 w/w ratio with grape marc (GM), and olive leaves in 3:1 $w / w$ ratio with two-phase olive mill wastes (OL). WS were obtained from the Thessaly region (central Greece), GM from a winery in the Nemea area (northeast Peloponnese, Greece) and OL from 
an olive-oil mill in Kalamata (southwest Peloponnese, Greece). Spawn and substrate preparation methodologies as well as mushroom cultivation conditions were as previously described [8,9].

\subsection{Sample Pre-Treatment}

Mushroom samples (in triplicates) from each treatment were freeze-dried (HetoLyolab3000, Heto-Holten, Allerød, Denmark), pulverized, placed in plastic bags and kept at $-40{ }^{\circ} \mathrm{C}$ until analysis. The same procedure was followed for substrate samples.

\subsection{Extraction of Free Amino Acids}

Free amino acids were extracted from freeze-dried mushrooms and substrates, essentially as described by Elmore et al. [50], with minor modifications. For the extraction, $300 \mathrm{mg}$ of each sample were placed into $15 \mathrm{~mL}$ screw capped vials, $5 \mathrm{~mL}$ of hydrochloric acid $0.01 \mathrm{M}$ was added and the samples were stirred for $15 \mathrm{~min}$ at room temperature on a magnetic stirrer plate. The extracts were allowed to settle for $45 \mathrm{~min}$ and then $1 \mathrm{~mL}$ aliquots of the supernatants were transferred to Eppendorf tubes and centrifuged at $7200 \times g$ for $30 \mathrm{~min}$. The centrifuged supernatants were stored at $-40^{\circ} \mathrm{C}$ until AA analysis.

\subsection{Crude Protein Content}

Crude protein was calculated in freeze-dried substrate and mushroom samples on the basis of their nitrogen content which was determined by the Kjeldahl method using the converting factor ' 4.38 ' for mushroom samples [51] and ' 6.25 ' for cultivation substrates.

\subsection{Derivatization of Free Amino Acids}

FAAs profiling of the studied mushrooms and substrates was conducted using the EZ:faast ${ }^{\mathrm{TM}}$ amino acid derivatization technique for GC-MS (Phenomenex ${ }^{\circledR}$, Torrance, CA, USA) [19]. The procedure consists of a solid phase extraction step followed by AAs derivatization and liquid/liquid extraction of the derivatives. According to the protocol, $100 \mu \mathrm{L}$ aliquots of the centrifuged extracts were placed into the sample preparation vials provided, along with $20 \mathrm{nmol}$ of norvaline as internal standard, followed by a solid phase extraction performed via sorbent tips that bind the AA derivatives, while allowing interfering compounds to flow through. The two-steps derivatization of the AAs was carried out at room temperature; the derivatized AAs were extracted into $100 \mu \mathrm{L}$ of isooctane/chloroform, sealed in GC vials and analyzed immediately.

\subsection{GC/MS Analysis of Free Amino Acids}

An Agilent GC 6890N gas chromatograph (Waldbronn, Germany), coupled with an HP5973 Mass Selective detector (Electron Impact, $70 \mathrm{eV}$ ), split-splitless injector and an HP7683 auto sampler was used for the analysis. Two $\mu \mathrm{L}$ of derivatized samples were injected into GC at a split ratio of 1:15. The separation was achieved using a Phenomenex Zebron ZB-A AAs analysis dedicated column (length $=10 \mathrm{~m}$, internal diameter $=0.25 \mathrm{~mm}$, film thickness $=25 \mu \mathrm{m}$ ). High purity helium was the carrier gas at a constant flow of $1.1 \mathrm{~mL} / \mathrm{min}$. The injector and transfer line temperatures were kept at 250 and $340{ }^{\circ} \mathrm{C}$, respectively. The initial oven temperature was set at $110{ }^{\circ} \mathrm{C}$, then increased to $320^{\circ} \mathrm{C}$ at $30^{\circ} \mathrm{C} / \mathrm{min}$ where it was held for $3 \mathrm{~min}$. A selective ion monitoring (SIM) GC-MS method was applied for the detection and quantification of $22 \mathrm{AAs}$, based on the $\pm 0.05 \mathrm{RT}$ presence of target and qualifier ions at the predetermined ratios, together with the electronic library "Agilent.L" provided with the Ez:faast kit (Phenomenex ${ }^{\circledR}$, Torrance, CA, USA). Quantification was carried out by employing norvaline as internal standard and constructing five points' reference curves for each AA by standard AAs solutions provided with the kit. GABA, which was not present in the standards of the kit, was quantitated in the same way by employing pure GABA purchased from Sigma and by extracting the respective $\mathrm{m} / \mathrm{z}$ ions (Supplementary Table S1). 


\subsection{Statistical Analysis}

All chemical analyses were performed in triplicate and data are presented as mean \pm standard deviation. The Kolmogorov-Smirnov and Shapiro-Wilk tests were used to assess the normality of the data. As both tests provided $p$ values $>0.05$ the null hypothesis, i.e., that the data are not normally distributed, was rejected and differences between means were established by conducting one-way ANOVA and Duncan's t-test (5\% level of probability).

In addition, PCA was performed on the entire AAs data set to attain an overview of possible interrelation between the AAs and the Pleurotus species examined. Statistical analysis was conducted with the SPSS software (SPSS for Windows, version 21.0, SPSS Inc., Chicago, IL, USA) and R-studio1.0.136/R3.3.3 loaded with the "ade4" and "adegraphics" packages.

Supplementary Materials: The following are available online, Supplementary Table S1: Retention times (Rt) and $\mathrm{m} / \mathrm{z}$ of ions used for the selective ion monitoring of amino acids. Supplementary Table S2: Groups of free amino acids in Pleurotus mushrooms compared on the basis of the cultivation substrate used for each strain. Supplementary Figure S1: Score plot of PCA (PC1 vs. PC2) for the discrimination of Pleurotus cultivation substrates (GM, wheat straw with grape marc $(1: 1 w / w)$; OL, olive leaves with olive mill wastes (3:1 w/w ratio); WS, wheat straw).

Author Contributions: Conceptualization, N.K. and G.I.Z.; implementation of experiments, D.T., G.B. and G.K.; validation, D.T., A.K., G.B., M.C., G.I.Z. and N.K.; data analysis, D.T., G.B. and G.K.; writing-original draft preparation, D.T.; writing-final draft preparation, N.K. and G.I.Z.; review and editing, D.T., A.K., G.B., G.K., M.C., G.I.Z. and N.K.; supervision, N.K. and G.I.Z.; project administration, N.K. and G.I.Z; funding acquisition, N.K. and G.I.Z. All authors have read and agreed to the published version of the manuscript.

Funding: This research has been co-financed by the European Union and Greek national funds (European Social Fund-ESF) through the Operational Program Competitiveness, Entrepreneurship and Innovation, under the call RESEARCH-CREATE-INNOVATE (project code: T1EDK-02560).

Conflicts of Interest: The authors declare no conflict of interest.

\section{References}

1. Valverde, M.E.; Hernández-Pérez, T.; Paredes-López, O. Edible mushrooms: Improving human health and promoting quality life. Int. J. Microbiol. 2015, 2015, 1-14. [CrossRef] [PubMed]

2. Dicks, L.; Ellinger, S. Effect of the intake of oyster mushrooms (Pleurotus ostreatus) on cardiometabolic parameters-A systematic review of clinical trials. Nutrients 2020, 12, 1134. [CrossRef] [PubMed]

3. Gargano, M.L.; van Griensven, L.J.L.D.; Isikhuemhen, O.S.; Lindequist, U.; Venturella, G.; Wasser, S.P.; Zervakis, G.I. Medicinal mushrooms: Valuable biological resources of high exploitation potential. Plant Biosyst. 2017, 151, 548-565. [CrossRef]

4. Royse, D.J.; Baars, J.; Tan, Q. Current overview of mushroom production in the world. In Edible and Medicinal Mushrooms: Technology and Applications; John Wiley \& Sons Ltd.: Hoboken, NJ, USA, 2017; pp. 5-13. [CrossRef]

5. Zervakis, G.I.; Ntougias, S.; Gargano, M.L.; Besi, M.I.; Polemis, E.; Typas, M.A.; Venturella, G. A reappraisal of the Pleurotus eryngii complex-New species and taxonomic combinations based on the application of a polyphasic approach, and an identification key to Pleurotus taxa associated with Apiaceae plants. Fungal Biol. 2014, 118, 814-834. [CrossRef]

6. Ritota, M.; Manzi, P. Pleurotus spp. Cultivation on different agri-food by-products: Example of biotechnological application. Sustainability 2019, 11, 5049. [CrossRef]

7. Zervakis, G.I.; Koutrotsios, G. Solid state fermentation of plant residues and agro-industrial wastes for the production of medicinal mushrooms. In Medicinal Plants and Fungi: Recent Advances in Research and Development; Agrawal, D.C., Tsay, H.-S., Shyur, L.-F., Wu, Y.-C., Wang, S.-Y., Eds.; Springer Nature Singapore: Singapore, 2017; pp. 365-396. [CrossRef]

8. Koutrotsios, G.; Kalogeropoulos, N.; Kaliora, A.C.; Zervakis, G.I. Toward an increased functionality in oyster (Pleurotus) mushrooms produced on grape marc or olive mill wastes serving as sources of bioactive compounds. J. Agric. Food Chem. 2018, 66, 5971-5983. [CrossRef] 
9. Koutrotsios, G.; Mountzouris, K.C.; Chatzipavlidis, I.; Zervakis, G.I. Bioconversion of lignocellulosic residues by Agrocybe cylindracea and Pleurotus ostreatus mushroom fungi-Assessment of their effect on the final product and spent substrate properties. Food Chem. 2014, 161, 127-135. [CrossRef]

10. Koutrotsios, G.; Patsou, M.; Mitsou, E.K.; Bekiaris, G.; Kotsou, M.; Tarantilis, P.A.; Pletsa, V.; Kyriacou, A.; Zervakis, G.I. Valorization of olive by-products as substrates for the cultivation of Ganoderma lucidum and Pleurotus ostreatus mushrooms with enhanced functional and prebiotic properties. Catalysts 2019, 9, 537. [CrossRef]

11. Bao, X.; Feng, Z.; Yao, J.; Li, T.; Yin, Y. Roles of dietary amino acids and their metabolites in pathogenesis of inflammatory bowel disease. Mediators Inflamm. 2017, 2017, 1-9. [CrossRef]

12. Mau, J.L.; Lin, Y.P.; Chen, P.T.; Wu, Y.H.; Peng, J.T. Flavor compounds in king oyster mushrooms Pleurotus eryngii. J. Agric. Food Chem. 1998, 46, 4587-4591. [CrossRef]

13. Mau, J.-L.; Lin, H.-C.; Chen, C.-C. Non-volatile components of several medicinal mushrooms. Food Res. Int. 2001, 34, 521-526. [CrossRef]

14. Tseng, Y.H.; Lee, Y.L.; Li, R.C.; Mau, J.L. Non-volatile flavour components of Ganoderma tsugae. Food Chem. 2005, 90, 409-415. [CrossRef]

15. Yang, J.-H.; Lin, H.-C.; Mau, J.-L. Non-volatile taste components of several commercial mushrooms. Food Chem. 2001, 72, 465-471. [CrossRef]

16. Mau, J.L. The umami taste of edible and medicinal mushrooms. Int. J. Med. Mushrooms 2005, 7, 119-125. [CrossRef]

17. Patel, S.; Goyal, A. Recent developments in mushrooms as anti-cancer therapeutics: A review. 3 Biotech 2012, 2, 1-15. [CrossRef] [PubMed]

18. Sánchez, C. Modern aspects of mushroom culture technology. Appl. Microbiol. Biotechnol. 2004, 64, 756-762. [CrossRef]

19. EZ:faast Free (Physiological) Amino Acid Analysis by GC-MS, User's Manual. Available online: https: //phenomenex.blob.core.windows.net/documents/3eaba18b-9083-4760-bbe5-a511c0d9df21.pdf (accessed on 7 November 2019).

20. Badawy, A.A.B.; Morgan, C.J.; Turner, J.A. Application of the Phenomenex EZ: faast ${ }^{\mathrm{TM}}$ amino acid analysis kit for rapid gas-chromatographic determination of concentrations of plasma tryptophan and its brain uptake competitors. Amino Acids 2008, 34, 587-596. [CrossRef]

21. Baddi, G.A.; Alburquerque, J.A.; Gonzálvez, J.; Cegarra, J.; Hafidi, M. Chemical and spectroscopic analyses of organic matter transformations during composting of olive mill wastes. Int. Biodeterior. Biodegrad. 2004, 54, 39-44. [CrossRef]

22. Feedipedia, an On-Line Encyclopedia of Animal Feeds. Available online: https://www.feedipedia.org (accessed on 2 July 2020).

23. Li, W.; Gu, Z.; Yang, Y.; Zhou, S.; Liu, Y.; Zhang, J. Non-volatile taste components of several cultivated mushrooms. Food Chem. 2014, 143, 427-431. [CrossRef]

24. Cohen, N.; Cohen, J.; Asatiani, M.D.; Varshney, V.K.; Yu, H.T.; Yang, Y.C.; Li, Y.H.; Mau, J.L.; Wasser, S.P. Chemical composition and nutritional and medicinal value of fruit bodies and submerged cultured mycelia of culinary-medicinal higher basidiomycetes mushrooms. Int. J. Med. Mushrooms 2014, 16, 273-291. [CrossRef]

25. Bach, F.; Helm, C.V.; Bellettini, M.B.; Maciel, G.M.; Haminiuk, C.W.I. Edible mushrooms: A potential source of essential amino acids, glucans and minerals. Int. J. Food Sci. Technol. 2017, 52, 2382-2392. [CrossRef]

26. Kim, M.Y.; Chung, M.; Lee, S.J.; Ahn, J.K.; Kim, E.H.; Kim, M.J.; Kim, S.L.; Moon, H.I.; Ro, H.M.; Kang, E.Y.; et al. Comparison of free amino acid, carbohydrates concentrations in Korean edible and medicinal mushrooms. Food Chem. 2009, 113, 386-393. [CrossRef]

27. Guo, L.Q.; Lin, J.Y.; Lin, J.F. Non-volatile components of several novel species of edible fungi in China. Food Chem. 2007, 100, 643-649. [CrossRef]

28. Yin, C.; Fan, X.; Fan, Z.; Shi, D.; Yao, F.; Gao, H. Comparison of non-volatile and volatile flavor compounds in six Pleurotus mushrooms. J. Sci. Food Agric. 2019, 99, 1691-1699. [CrossRef]

29. Gao, S.; Huang, Z.; Feng, X.; Bian, Y.; Huang, W.; Liu, Y. Bioconversion of rice straw agro-residues by Lentinula edodes and evaluation of non-volatile taste compounds in mushrooms. Sci. Rep. 2020, 10, 1814. [CrossRef]

30. Manzi, P.; Gambelli, L.; Marconi, S.; Vivanti, V.; Pizzoferrato, L. Nutrients in edible mushrooms: An inter-species comparative study. Food Chem. 1999, 65, 477-482. [CrossRef] 
31. Breene, W.M. Nutritional and medicinal value of specialty mushrooms. J. Food Prot. 1990, 53, 883-894. [CrossRef]

32. Dundar, A.; Acay, H.; Yildiz, A. Yield performances and nutritional contents of three oyster mushroom species cultivated on wheat stalk. Afr. J. Biotechnol. 2008, 7, 3497-3501. [CrossRef]

33. Miyazawa, N.; Matsuoka, H.; Ozawa, Y. Palatability characteristics of Pleurotus eryngii var. tuoliensis. Nippon Shokuhin Kagaku Kogaku Kaishi 2012, 59, 153-160. [CrossRef]

34. Yoshida, H.; Sasaki, H.; Fujimoto, S.; Sugahara, T. The chemical components of the vegetative mycelia of Basidiomycetes. Nippon Shokuhin Kogyo Gakkai-Shi 1996, 43, 748-755. [CrossRef]

35. Patil, S.S.; Ahmed, S.A.; Telang, S.M.; Baig, M.M.V. The nutritional value of Pleurotus ostreatus (Jacq.:Fr.) Kumm cultivated on different lignocellulosic agro-wastes. Innov. Rom. Food Biotechnol. 2010, 7, 66-76.

36. Bamidele, O.P.; Fasogbon, B.M. Nutritional and functional properties of maize-oyster mushroom (Zea mays-Pleurotus ostreatus) based composite flour and its storage stability. Open Agric. 2020, 5, 40-49. [CrossRef]

37. Oyetayo, F.L.; Akindahunsi, A.; Oyetayo, V.O. Chemical profile and amino acids composition of edible mushrooms Pleurotus sajor-caju. Nutr. Health 2007, 18, 383-389. [CrossRef] [PubMed]

38. Papada, E.; Amerikanou, C.; Torović, L.; Kalogeropoulos, N.; Tzavara, C.; Forbes, A.; Kaliora, A.C. Plasma free amino acid profile in quiescent Inflammatory Bowel Disease patients orally administered with Mastiha (Pistacia lentiscus); a randomised clinical trial. Phytomedicine 2019, 56, 40-47. [CrossRef]

39. Kothari, D.; Patel, S.; Kim, S.K. Anticancer and other therapeutic relevance of mushroom polysaccharides: A holistic appraisal. Biomed. Pharmacother. 2018, 105, 377-394. [CrossRef]

40. Khan, A.A.; Gani, A.; Khanday, F.A.; Masoodi, F.A. Biological and pharmaceutical activities of mushroom $\beta$-glucan discussed as a potential functional food ingredient. Bioact. Carbohydrates Diet. Fibre 2018, 16, 1-13. [CrossRef]

41. Beluhan, S.; Ranogajec, A. Chemical composition and non-volatile components of Croatian wild edible mushrooms. Food Chem. 2011, 124, 1076-1082. [CrossRef]

42. Diana, M.; Quílez, J.; Rafecas, M. Gamma-aminobutyric acid as a bioactive compound in foods: A review. J. Funct. Foods 2014, 10, 407-420. [CrossRef]

43. Sivashanmugam, M.; Jaidev, J.; Umashankar, V.; Sulochana, K.N. Ornithine and its role in metabolic diseases: An appraisal. Biomed. Pharmacother. 2017, 86, 185-194. [CrossRef]

44. Lin, S.Y.; Chen, Y.K.; Yu, H.T.; Barseghyan, G.S.; Asatiani, M.D.; Wasser, S.P.; Mau, J.L. Comparative study of contents of several bioactive components in fruiting bodies and mycelia of culinary-medicinal mushrooms. Int. J. Med. Mushrooms 2013, 15, 315-323. [CrossRef]

45. Park, Y.-J.; Oh, T.-S.; Jang, M.-J. Effect of adding amino acids on the production of Gamma-Aminobutyric Acid (GABA) by mycelium of Lentinula edodes. Int. J. Food Eng. 2019, 15, 1-6. [CrossRef]

46. Narayan, V.S.; Nair, P.M. Metabolism, enzymology and possible roles of 4-aminobutyrate in higher plants. Phytochemistry 1990, 29, 367-375. [CrossRef]

47. Yamaguchi, S. Basic properties of umami and effects on humans. Physiol. Behav. 1991, 49, 833-841. [CrossRef]

48. Kirimura, J.; Shimizu, A.; Kimizuka, A.; Ninomiya, T.; Katsuya, N. Contribution of peptides and amino acids to the taste of foods. J. Agric. Food Chem. 1969, 17, 689-695. [CrossRef]

49. Dong, M.; Qin, L.; Xue, J.; Du, M.; Lin, S.-Y.; Xu, X.-B.; Zhu, B.-W. Simultaneous quantification of free amino acids and $5^{\prime}$-nucleotides in shiitake mushrooms by stable isotope labeling-LC-MS/MS analysis. Food Chem. 2018, 268, 57-65. [CrossRef]

50. Elmore, S.J.; Koutsidis, G.; Dodson, A.T.; Mottram, D.S.; Wedzicha, B.L. Measurement of acrylamide and its precursors in potato, wheat, and rye model systems. J. Agric. Food Chem. 2005, 53, 1286-1293. [CrossRef]

51. Kalač, P. Chemical composition and nutritional value of European species of wild growing mushrooms: A review. Food Chem. 2009, 113, 9-16. [CrossRef]

Sample Availability: Samples of the compounds are available from the authors.

(C) 2020 by the authors. Licensee MDPI, Basel, Switzerland. This article is an open access article distributed under the terms and conditions of the Creative Commons Attribution (CC BY) license (http://creativecommons.org/licenses/by/4.0/). 